$10-2016$

\title{
Film Review: Son of Saul
}

\section{Carla Rose Shapiro}

University of Toronto

Follow this and additional works at: https://digitalcommons.usf.edu/gsp

\section{Recommended Citation}

Shapiro, Carla Rose (2016) "Film Review: Son of Saul," Genocide Studies and Prevention: An International Journal: Vol. 10: Iss. 2: 151-158.

DOI:

http://dx.doi.org/10.5038/1911-9933.10.2.1437

Available at: https://digitalcommons.usf.edu/gsp/vol10/iss2/17

This Film Review is brought to you for free and open access by the Open Access Journals at Digital Commons @ University of South Florida. It has been accepted for inclusion in Genocide Studies and Prevention: An International Journal by an authorized editor of Digital Commons @ University of South Florida. For more information, please contact digitalcommons@usf.edu. 
Film Review: Son of Saul

Carla Rose Shapiro

Independent Scholar

Son of Saul

Director: László Nemes

Hungary, 2015

Reviewed by Carla Rose Shapiro

Independent Scholar

Auschwitz presents "a multiplicity of realities, a multiplicity of meanings, perspectives and approaches that co-exist simultaneously." ${ }^{1}$ Son of Saul is director László Nemes' cinematic interpretation of one specific perspective of Auschwitz as envisaged by the film's protagonist, Saul Ausländer, a prisoner of the camp, who, as a member of the Sonderkommando, was assigned a particularly onerous task-working in the gas chambers and crematoria of Auschwitz-Birkenau. Son of Saul should have provoked debate about the enactment of those events, and the placement of a camera at the threshold of that sacral, albeit mimetic space. If, according to Theodor Adorno, writing poetry after Auschwitz is barbaric, ${ }^{2}$ what about creative endeavours seventy years after Auschwitz? With the passage of time between the realities of Auschwitz and their contemporary re-creation, the boundaries of the limits of representation have become increasingly indistinct. The near universal praise from film critics, and numerous prestigious awards bestowed upon Son of Saul (such as the Grand Prix at the 2015 Cannes Film Festival and the Academy Award for Best Foreign Language Film), suggest an almost unquestioned acceptance of the film's leitmotif, which is no longer considered artistically transgressive in this visually permissive YouTube era. The film's acclaim, coupled with affirmative nods from French philosopher Georges Didi-Huberman ${ }^{3}$ and filmmaker Claude Lanzmann ${ }^{4}$ (who has long rejected fictional cinematic representations of the Holocaust) seem to support Son of Saul as both a tour de force and the realization of an effective representational strategy within the challenging genre of Holocaust cinema. Son of Saul is a demanding film that is difficult to watch; it takes the audience on a journey where few artistic endeavours have gone before. By setting the film in the gas chambers and crematoria of AuschwitzBirkenau, and by expressing that he "wanted to show people how the situation really was" ${ }^{5}$, Nemes sets the moral and representational stakes high; a critique of the film must therefore be considered accordingly.

More than one million victims, mostly Jews, died in Auschwitz-Birkenau, making it the most lethal of the Nazi concentration and death camps. The epicentre of the killing took place in the four crematoria buildings housed in Birkenau, the largest within a network of camps and subcamps which made up the Auschwitz complex. It is the main setting for Son of Saul, as evidenced by the unequivocal mise-en-scène of the film; the viewer is immediately plunged into the terror of this univers concentrationnaire. ${ }^{6}$ It is the latter half of 1944, the time gleaned from the storyline of the prisoner revolt, which resulted in the sabotage of Crematorium IV. The Sonderkommando, or Special Squads, were comprised of prisoners, predominantly Jewish, forced by the SS to usher

${ }^{1}$ Jonathan Webber, The Future of Auschwitz: Some Personal Reflections (Oxford: Oxford Centre for Postgraduate Hebrew Studies, 1992), 8.

${ }^{2}$ Theodor W. Adorno, "Cultural Criticism and Society," in Prisms, trans. Samuel and Shierry Weber (Cambridge, Massachusetts: MIT Press, 1981), 34.

${ }^{3}$ Georges Didi-Huberman, Sortir du noir (Paris: Les Editions de Minuit, 2015).

${ }^{4}$ Jordan Cronk, "'Shoah' Filmmaker Claude Lanzmann Talks Spielberg, 'Son of Saul'," The Hollywood Reporter, February 5, 2016, accessed March 18, 2016, http://www.hollywoodreporter.com/news/shoah-filmmaker-claude-lanzmanntalks-869931.

${ }^{5}$ Peter Howell, “TIFF: Son of Saul Actor Géza Röhrig on How He Came to Grips with Auschwitz Role," The Toronto Star, September 10, 2015, accessed March 16, 2016, http://www.thestar.com/entertainment/movies/2015/09/10/tiff-son-ofsaul-actor-gza-rhrig-on-how-he-came-to-grips-with-auschwitz-role.html.

${ }^{6}$ This term comes from the title of a book written by David Rousset, L'univers concentrationnaire (Paris: Editions de Pavois, 1946).

Carla Rose Shapiro, "Film Review: Son of Saul" Genocide Studies and Prevention 10, 2 (2016): 151-158. @2016 Genocide Studies and Prevention.

http://dx.doi.org/10.5038/1911-9933.10.2.1437 
victims to their deaths in the gas chambers and to dispose of their bodies. Eyewitness accounts written by members of the Sonderkommando, buried in 1944, were unearthed in the grounds of Birkenau after the camp's liberation and published as The Scrolls of Auschwit.? The testimonies contained in this book were the inspiration for Nemes and co-writer Clara Royer's script for Son of Saul.

Son of Saul accurately portrays certain mechanics of the Sonderkommando's grim undertakings. The film begins with the arrival of a new transport of Jews. Saul and his fellow Sonderkommando instruct the unsuspecting victims to undress and await a shower and hot soup. "Remember your hook number" a voice instructs the new arrivals. Son of Saul captures the deception perfectly - the undressing room is the antechamber to death. Moments after the gas chamber doors are slammed shut, the screams begin, getting louder and louder-then silence. The naked bodies of the dead are removed and the floor is scrubbed clean in preparation for the next victims. During one of the socalled operations, Saul witnesses a young boy survive the gas chamber. The child's resuscitation is but a momentary reprieve, as the boy is soon smothered to death by a Nazi camp doctor. Saul insists the dead boy is his own son, although we are never sure of the truth of this assertion, or whether the boy reminds him of his son or is a projection of a son he will never have. Saul searches frantically for a rabbi to perform the proper Jewish prayers and to somehow find a way in this incendiary hell to bury the child according to Jewish tradition. This quest appears obsessive and irrational, and one film critic even goes so far as to summarize Son of Saul as "a movie set in Auschwitz that concerns a member of the Sonderkommando who goes mad." ${ }^{8}$ Concurrent to this mission of ritual, Saul is recruited into Birkenau's resistance movement. Saul's role in the Sonderkommando revolt and his attempt to bury the boy are the two intertwined narratives that structure the film.

While cinematic representations of concentration camp privation and death are prone to aestheticization, Nemes does nothing to placate the harshness and ugliness of the events portrayed. He rejects decontextualized memory cues of the Holocaust, the clichés such as barbed-wire fences, smoke rising from crematoria chimneys, and victims passing though the "Arbeit macht frei" gateand forgoes a sentimental music soundtrack for only screams of terror. Nemes' script also avoids using conventional Hollywood narrative structures such as a hero-rescuer, successful escapes, or survival against the odds, which all offer up a positive narrative resolution. Through avoiding these tropes he denies the audience a happy ending or emotional catharsis à la Schindler's List (Steven Spielberg, 1993). He even shuns character identification and empathy. There is nothing particularly special or even likeable about Saul. We learn very little about him as a person or as a prisoner, and we know even less about the supposed son. Nemes here rightly acknowledges that within this massive loss of life, the stories and memories of individual lives forever remain unrecoverable. Son of Saul remains a film about people who were killed rather than a film about survivors, reflecting the reality of the Holocaust, that the vast majority of European Jewry did not survive. As Stanley Kubrick noted about Schindler's List, "The Holocaust is about six million people who get killed. Schindler's List is about 600 who don't." ${ }^{\prime \prime}$ Nemes' directorial choices, however, do not suggest that Son of Saul entirely eschews stylization or fully transcends cinematic conventions, or the dangers of the aesthetic seduction of violence.

Nemes implicitly explores what Primo Levi describes in his book The Drowned and the Saved as "the grey zone," in his depiction of the work assigned to the Sonderkommando. The grey zone was the ambiguous ethical space inhabited by the Sonderkommando-an area outside the boundaries of usual human morality where the categories of guilt or innocence, perpetrator or

\footnotetext{
${ }^{7}$ Ber Mark, ed. The Scrolls of Auschwitz, trans. Sharon Neemani (Tel Aviv: Am Oved Publishers Ltd., 1985). Books by surviving members of the Sonderkommando were also likely used as resources, such as Shlomo Venezia's Inside the Gas Chambers: Eight Months in the Sonderkommando of Auschwitz and Filip Müller's Eyewitness Auschwitz: Three Years in the Gas Chambers.

${ }^{8}$ J. Hoberman, “10 Can't-Miss Films of 2015,” Tablet Magazine, December 16, 2015, accessed April 9, 2016, http://www. tabletmag.com/scroll/195866/10-cant-miss-films-of-2015.

${ }^{9}$ Stanley Kubrick quoted in Liel Leibovitz, “Listless," Tablet Magazine, December 13, 2011, accessed April 11, 2016, http:// www.tabletmag.com/jewish-arts-and-culture/85945/listless.
} 
victim are not easily applied. Levi considers the formation of the Sonderkommando to be one of the most insidious crimes of the Nazi regime; that is, forcing Jewish prisoners to participate in the destruction of their own community. Were the Sonderkommando collaborators who betrayed their fellow Jews in return for a momentary reprieve from their own demise? Or were they as much the victims of Nazi oppression as other prisoners in the concentration camps? The Sonderkommando, the "bearer of secrets" as the film's only intertitle states, held additional burdens not experienced by other camp prisoners in both the secrecy of their actions and the guilt at having participated in the process of murder. Even though the Sonderkommando hold a highly contested place in Holocaust history, the film's articulation of the predicament of the Sonderkommando within this grey zone is inadequate. While an exploration of the grey zone as a central theme in the film may not have been the intention of the filmmaker, the necessary, (but unanswerable) questions which should be provoked by the tragic moral quandary of the Sonderkommando, are difficult to form within the paucity of the film's frames of reference. ${ }^{10}$

In crafting a film with abstract messages, each viewer journeys through this nightmarish nether world responsible for their own interpretive work. Son of Saul seems to explore the necessity of meaning in life even within a state of suffering - perhaps a cinematic reading of Viktor Frankl's Man's Search for Meaning. ${ }^{11}$ The film never makes clear why Saul is so determined to bury the boy. Regardless of whether the boy is, in fact, the son of Saul, Saul's quest to give the child a proper burial infuses his life with a sense of purpose. It is through the performance of a universally-held ritual that Saul sees one last tenuous link to life as it was lived "before." Saul's final meaningful act connects him to ethical humanity and enables him to feel again; it is a transformational act. In Son of Saul, the necessity of meaning is given precedence over the cause of the resistance and even over survival itself. A fellow Sonderkommando, Abraham, reprimands Saul: "You failed the living for the dead." The film purports to explore the material and spiritual facets of resistance and the nature of survival, but in pushing Saul's obsession to the brink of madness, the credibility of Saul's character as a conduit for such questions becomes suspect.

Son of Saul engages with the issue of the radical de-subjectification of the victims of the Holocaust by giving agency to a seemingly powerless Auschwitz prisoner. In the film de-subjectification is starkly expressed when Nazi officers refer to the murdered Jews as "pieces" - they yell orders to the Sonderkommando, "move the pieces, burn the pieces." The victims have become mere physical objects to be processed and then disposed of. Saul's quest for a ritual burial for the child is a kind of refutation of this ultimate loss of subjectivity. No matter how futile, Saul's actions are perhaps meant to serve as a corrective to the perception of Jews through the lens of Nazi history, as weak, passive, and lacking in any sense of agency; abject images from liberator's and movie director's cameras further perpetuate Jews as representational victims. However, with the exception of the boy, victims in the film are still denied their individuality and subjectivity by being shown as anonymous heaps in burn pits or blurred corpses being dragged out of the gas chambers. The victims remain objectified and dehumanized. The film reiterates the perpetrator's perspective, that the dead are just a mass of corpses, nothing more. With poor character development of Saul's Sonderkommando comrades, and other minor dramatis personae, neither the living nor the dead victims in Son of Saul are recovered from the impersonal machinery of destruction.

Nemes appears to take an ethical position on the representation of atrocity through his particular use of technique. Son of Saul focuses on the experience of one individual, Saul Ausländer; the film is from the visual and experiential viewpoint of that single witness. In all but a handful of shots, the viewer sees Birkenau through the eyes of Saul. The square visual format (a 4:3 aspect ratio), and use of medium and extreme close-up shots of Saul (who is typically placed in the centre of the frame), combined with the camera's shallow depth of field, provides a severely limited visual perspective, creating a feeling of confinement and claustrophobia. Echoing the fear and confusion of the victims upon entry into the camp, the camera intentionally throws spectators off balance. Long, unbroken hand-held shots add to the film's rawness. On top of providing no orienting shots

\footnotetext{
${ }^{10}$ A similar failure to describe the essence of Levi's conception can be seen in Tim Blake Nelson's 2001 film The Grey Zone, which also focuses on the Sonderkommando.

${ }^{11}$ Victor Frankl, Man's Search for Meaning: An Introduction to Logotherapy (New York: Simon \& Schuster, 1984).
} 
that grant a wider view of the camp, Nemes provides nominal visual references with few narrative clues to situate the characters or the action. What little space is left in the visual field is usually out of focus and/or in partial view. In this oblique approach to representation, the brutality of the murder process occurs just beyond our line of sight, or is shown at the edges of the filmic space. The violence and its aftermath is suggested rather than clearly visible. While these techniques are both effective and affective, they are not original, as some film critics have noted. ${ }^{12}$ One also questions whether a blurred representation of systematic murder set in the periphery of the frame resolves the representational challenges of depicting atrocity.

Nemes deviates from his own methodology, oscillating between mostly oblique visuals, graphic glimpses, and explicit sounds. From being indistinct and hazy, bits and pieces of the bodies come into focus. In this way, Nemes forwards a representational double standard, with the horrors of Birkenau situated on the periphery, but the referent is unmistakable; we see quick flashes of naked, dead bodies being dragged away over concrete floors stained with excreta and corpses being fed into ovens. In one memorable scene, a column of recently arrived victims is pushed to the edges of a pit where they are shot to death at close range. The brutality is excessive, not only in its aestheticization of violence but in the fact that such shootings in pits, while typical of the mass-murder operations of the Einsatzgruppen in the occupied Soviet Union, did not occur in Auschwitz. ${ }^{13}$ A death camp seems like the last place where violence would need to be embellished.

It is the close-up detail of the corpses of dead women that appears in the aftermath of a gas chamber sequence that is among the most problematic visuals in the movie. In the scenes set in the crematoria, both naked male and female bodies are evident. However, in one sequence the camera lingers, in focus, on a voluminous breast. The positioning of the corpse in a sexualized manner and the cropping of the image leaves the victim disembodied. One could argue that the expression of the perpetrator's sheer power over the victim, and the brutality of the murder is correctly corelated to images of the dismemberment of the female body. But Son of Saul more consistently neglects the consideration of gender in the Nazi's process of dehumanizing their victims, and in the manner in which the Final Solution was carried out. While there was an ultimate common fate for all Jews during the Holocaust, Jewish women were victimized as Jews, and as women. Upon arrival at Auschwitz, men and women had an unequal chance of surviving the initial selection process. And, visibly pregnant women, and women with infants and young children were immediately consigned to the gas chambers. The film could have succinctly conveyed these realities without disrupting the two principal storylines, but did not, and thus the placement of the cadaver in the aftermath of the gassings was likely not intended as a comment on the vulnerabilities and exploitation faced by women in the concentration camp system; rather Nemes' inclusion of the violated female body elicits possible scopophilic responses.

Son of Saul is mostly a wordless film, but it is by no means silent. The technically impressive sound design by Tamás Zányi serves not only to augment the visuals but acts as a representational proxy for the un-visualized. For example, it is through the marrying of images and sound that the chaos and fear experienced by people being unloaded from the transports and prodded into the unknown is vividly captured. These scenes in particular ring true to survivor accounts of arriving at Auschwitz, and they reflect the fact that there were "no smoothly functioning killing

\footnotetext{
${ }^{12}$ For example, Richard Roeper, "Son of Saul': An Original, Devastating Take on the Holocaust," Chicago Sun Times, January 28, 2016, accessed March 23, 2016, http://chicago.suntimes.com/entertainment/son-of-saul-an-original-takeon-the-holocaust-breathtaking-and-devastating/ and Steve Pond, "Son of Saul' Cannes Review: Rookie Director Shocks Festival with Wrenching Holocaust Drama," The Wrap, May 14, 2015, accessed April 2, 2016, http://www.thewrap.com/cannes-film-festival-2015-review-son-of-saul-holocaust-drama/.

${ }^{13}$ During the Hungarian Action in 1944, thousands of Jews who arrived daily were murdered in the gas chambers; there was a relatively small number of Jews who were not able to walk to crematoria and they were shot on a ramp outside of Birkenau. See Robert Jan van Pelt, The Case for Auschwitz: Evidence from the Irving Trial (Bloomington and Indianapolis: Indiana UP, 2002), 187. Shootings did take place in the yard of Block 11 of Auschwitz 1, with the victims being mostly Soviet prisoners of war and Poles. There were executions in the gravel pit area just outside of walls of Auschwitz, but these did not involve victims of the Hungarian Action. See the Auschwitz-Birkenau Memorial and Museum, "Shooting," accessed April 7, 2016, http://auschwitz.org/en/history/punishments-and-executions/shooting.
} 
machines, quick deaths, or German efficiency when it came to mass murder."14 While the film visualizes the "before" and the "after," the actual moment of murder through gassing is conveyed through a horrific collection of sounds. Nemes' camera, by focusing on Saul, does not enter the gas chamber before or during the gassing. Sounds are used as part of the imagining of the horrific events occurring in the interior of the gas chamber-the thud of the gas chamber door, the pounding of hands from the inside, the screams and moans of the victims. The not seen, or the barely seen but heard, leaves the rest to the viewer's imagination (although very little is left to the imagination). If the point had not already made, the Sonderkommando enter the chamber after the murder by Zyklon B to take away the bodies and clean the space in preparation for the next group. While Nemes has crafted a sensory and visceral film experience that transports the audience to the right "there" of constant fear and dread this scene serves as an admonition: we understand cinema's inadequacy as a medium for recovering the fact and memory of Birkenau's industrial-scale mass murder. Within this mimesis there is also an obscenity-that some inchoate representational limit may have been breached. If, as cultural theorist Andreas Huyssen believes, the question of Holocaust representation will always return to the problem of unspeakability, then the gas chambers of Birkenau should be that place of silence. Just because one can depict, does not mean one should. Does hearing rather than seeing the murder process, make it any less representationally problematic? But beyond theoretical issues related to representation, a simpler and more general question should be posed - what does cinema at this abyss advance?

Nemes' representational approach, that of an experiential and immersive cinematic encounter, does not facilitate an understanding of the history of the Holocaust. While Son of Saul does not purport to be a historical film, it employs a specific historical setting and quotes actual historical events that took place in Auschwitz-Birkenau. History, however, seems more of a backdrop to Saul's story, and just as the composition of the film gives us a limited view of the actions taking place, the larger history is also kept outside the frame. The focus on the character of Saul comes at the expense of the broader context. Too little information is provided as guidance to viewers unfamiliar with the Holocaust, which leads one to wonder what audiences Nemes had in mind while crafting his film? In order to properly follow its storylines, Son of Saul demands a certain level of knowledge from its viewers. It seems surprising that Nemes assumed such knowledge, even for a Hungarian audience. One could leave this film not actually knowing something about the Holocaust as it unfolded at Auschwitz. Do we understand the scale of the crimes committed at Auschwitz and during the Holocaust in general? Why did Nemes open the film with an intertitle about the Sonderkommando but choose to provide absolutely no information about the Holocaust and Auschwitz-Birkenau something akin to an exhibition didactic panel, in film intertitle form, containing brief and concise orienting text? No film can offer a comprehensive or totalizing understanding of Auschwitz, or the Holocaust. However, Nemes' technique of contextual minimalism, and the privileging of immersive and impressionistic memory, risks at least the partial erasure of the specific historical events referred to in the film. How does such an approach promote Holocaust remembrance and education, which surely must have been one of the motivating factors behind the creation of this film?

Son of Saul can be said to offer an artistic response to the catastrophe of the Holocaust, situated between the demands of historical veracity and the more malleable needs of artistic interpretation. All art involves some rearranging of the facts in its imaginative reworking of reality. The artifices of stylization, and narrativization, for example, have the potential to impose unreliable and untruthful structures that occlude the historical memory of the Holocaust, but not necessarily so. Popular culture representations such as films have been delegitimized by being unfairly juxtaposed with some absolute standard of historical truth. By evaluating film as history, and only on history's terms, the ability of film to provide both historical awareness and entertainment is not fully contemplated. Son of Saul makes us consider the very fine balance necessary where both these demands converge in a film set in Auschwitz. The film is unsteady in negotiating both these interests, as fact and fiction intermingle freely, and the viewer left uncertain where they are

${ }^{14}$ Bettina Stangneth, Eichmann Before Jerusalem: The Unexamined Life of a Mass Murderer (Toronto: Random House of Canada Ltd., 2014), 278. 
within this dynamic. For those watching without in-depth knowledge of the history of the camp, it is difficult to know what events in the film are pure drama, what accounts are based on events which took place in the camp, and which scenes are a hybrid of fact and fiction. One example of this hybridization is the storyline that forms the basis for Saul's mission throughout the film. That a child was pulled from the gas chambers alive and then quickly put to death by a camp doctor was based on an account by Miklós Nyiszl, who had worked in Birkenau as a physician for the Sonderkommando and as a pathologist assisting Josef Mengele. He survived Auschwitz and wrote a chronicle of his life and work at the camp: Auschwitz: A Doctor's Eyewitness Account. ${ }^{15}$ Nemes takes Nyiszl's account and modifies it to suit the needs of the film, thereby fictionalizing a significant event in the historical record of Auschwitz.

Questionable are not the necessities of filmic abbreviations or the creative license taken to achieve an immersive spectatorial experience, but, rather, the overall abstraction of the film. Son of Saul alludes to specific events that took place in the camp but without describing them in enough detail to discern what is actually taking place. Who were the victims of Auschwitz that the film shows arriving in trains and leaving as ashes? The events depicted are likely the destruction of Hungary's Jewish community or the remnant of the Jews of the Lodz ghetto, but the film provides few clues as to the nationality or identity of these victims. Nor is there a clear chronology. The film opens in a time period just prior to the Sonderkommando revolt, which took place on October 7, 1944. From May until early July 1944, under the direction of Adolf Eichmann, in just eight weeks 437,000 Hungarian Jews were deported to Auschwitz-Birkenau; the camp reached its peak killing capacity during this time. It was during this brief period that one third of the total number of victims of Auschwitz were killed. ${ }^{16}$ More than 75 percent of those who were deported were murdered in the gas chambers of Auschwitz-Birkenau. In August, 67,000 Jews from the Lodz ghetto were transported to Auschwitz-Birkenau where 67 percent of them perished in the gas chambers. Son of Saul depicts a frantic rush to kill larger numbers of Jews even more rapidly. There is a specific historical reason for this. ${ }^{17}$ The impending defeat of the Third Reich, in the military sense, did not deter the other arm of the Nazi's total war-the genocidal campaign against the Jews, (the Final Solution) was not abandoned, but rather its pace accelerated. Early in the film the disposal of the murdered corpses takes place in the crematorium, but a later scene shows piles of bodies being burned in an area outside of the crematoria complex. During this last phase of murder in Auschwitz, the incoming volume was so great that the crematoria could not handle the volume, and corpses were incinerated in open-air pits. The incineration of the bodies of the victims was a part of the concealment of evidence of the mass murder that had taken place there. Son of Saul does not make these facts known and therefore misses an opportunity to inform its audience about this last critical phase in the destruction of European Jewry and thus diminishes the film's value for Holocaust and genocide education.

Saul's participation in the underground resistance is the other main narrative thread of the film. The storyline is punctuated by vague references to a planned rebellion among the Sonderkommando (snippets of conversation, items to be gathered), but Saul's assignments within the resistance are difficult to follow. There is a scene that takes place in a Birkenau warehouse where goods plundered from the victims are being sorted. A mysterious meeting between Saul and a female prisoner is arranged. Who is she and what is the nature of their relationship? She passes him a bundle. This visit is clearly linked to the revolt in the making, but like many other scenes in the film, the action is confusing. Was Saul facilitating the transfer of smuggled gunpowder to members of the camp's resistance movement? Toward the end of the film, a revolt does takes place, but it is difficult to understand the scope of this revolt; it appears that amid the chaos of the rebellion a few prisoners managed to escape, soon to be captured and killed by camp guards in quick pursuit.

\footnotetext{
${ }^{15}$ Nyiszl recalls in this book that a teenage girl had survived the gas chambers. She was found alive at the bottom of a pile of corpses. Nyiszl revived the girl, but soon after Erich Mussfeld, a supervising SS officer, perceived her to be a risk to the order of the camp, as a witness to the gas chambers, and ordered her to be killed.

${ }^{16}$ Debórah Dwork and Robert Jan Van Pelt, Auschwitz, 1270 To the Present (New York and London: W.W. Norton \& Company, 1996) 342-345.

${ }^{17}$ Leni Yahil, The Holocaust: The Fate of European Jewry, 1932-1945 (New York: Oxford UP, 1990), 499-524.
} 
It is curious that the film does not convey that the smuggled gunpowder was fashioned into the crudely-made grenades and explosives, which were used by the Sonderkommando to launch the uprising. Crematorium IV was destroyed in the revolt and never used again, but Son of Saul fails to describe the scale and "success" of the October 7, 1944, rebellion and the story of one of the most significant acts of resistance in the history of the Holocaust. The film omits the story of the important role that women played in the Sonderkommando rebellion. It was a group of Jewish women who smuggled small amounts of gunpowder from a munitions factory, located within the Auschwitz complex where they worked, to men and women in the camp's resistance movement and then eventually to the Sonderkommando. One of the key figures in the underground group responsible for smuggling the gunpowder was Róza Robota, who, like the mysterious woman in the film, worked at a clothing depot in Birkenau; one wonders why Nemes left the female figure in the depot so undeveloped as a character and the culmination of her courageous actions so vague.

Son of Saul touches upon another form of resistance-resistance through acts of documentation. The Nazis planned the total erasure of European Jewry, all the physical and evidentiary traces. Photographs taken by a Sonderkommando from inside Birkenau represent another significant act of resistance during the Holocaust - an act which, in the film, is inexplicably de-emphasized. Although none of the four photographs show the murder itself, the images, which capture the preparations for murder (a group of undressed women being readied for the gas chambers) and the aftermath (the Sonderkommando burning bodies in open-air incineration pits), are the only extant visual documents that depict the process of mass killing perpetrated at the gas chambers in Auschwitz-Birkenau. The Sonderkommando photographs are both an important expression of witnessing, documenting the lives of victims soon to be obliterated, and evidentiary documents whose purpose was to inform the outside world about the murderous events taking place at Auschwitz. These photographs represent a collective act of resistance by the organized underground movement: those who smuggled the camera into the camp, the photographer who captured the images, the people covering for the photographer, and those who smuggled the images out of the camp and handed them over to the Polish resistance. Saul is recruited by the resistance to provide cover for the Sonderkommando assigned to take the clandestine photographs by fixing a lock on a crematorium door. Saul's rescue of the entire mission-by sensing the approach of SS officers and quickly hiding the camera in a duct-appears as an incidental moment in the film and the gravity of this act is lost. The Sonderkommando photographs are exceptional visual documents of immense historical importance, yet in Son of Saul the viewer would not know that the events depicted are part of the recorded history of the camp. Nor would they learn about the fate of these photographs. Son of Saul passes over yet another opportunity to educate audiences about a pivotal event in the history of the Holocaust.

With its cache of high-profile awards and large audiences (by Holocaust film standards), Son of Saul is one of the texts now shaping the memory of the Holocaust and, by extension, impacting our culture's social awareness of the event. But what kind of memory and awareness is this film advancing? Nemes's filmmaking seems to acknowledge a shift in the representation of human suffering in an age of media saturation; the privileging of the evidentiary, the factual and the graphic in the interest of preventing atrocities, having not yielded positive results, has given rise to alternative approaches to memory-work. But Nemes's filmic memory-work presents audiences with too little and too much concurrently: there is a lack of explanation and reflection and an excess of sensorial disturbance. The problematic consistent throughout the film is that the complex and almost incomprehensible reality it refers to calls for more historical context than is provided. Perhaps Nemes purposefully rejects such attempts at elucidation, and in doing so suggests that there are neither simple meanings or lessons to take from the Holocaust. The Holocaust compels us to think deeply, and the disorientations and dislocations that Nemes places in the viewer's path may be those irritants that provoke individual contemplation, in contrast to the prescribed interpretations generally advanced in Holocaust-themed films. In refusing to offer explanations for one of the most complex historical events in human history, the film's equivocality may seem appropriate. However, rejecting the narratives of convention does not allow for the near complete rejection of the narrative of history. 
Title of the Film: Saul fia (Son of Saul); Director: László Nemes; Producers: Gábor Rajna, Gábor Sipos, Judit Stalter, Robert Vamos; Screenplay: László Nemes, Clara Royer; Cinematography: Mátyás Erdély; Film Editor: Matthieu Taponier; Sound Designer: Tamás Zányi; Country: Hungary; Year of Release: 2015; Production Company: Laokoon Filmgroup. Duration: 107 minutes.

\section{Bibliography}

Adorno, Theodor W. Prisms. Translated by: Samuel and Shierry Weber. Cambridge, Massachusetts: MIT Press, 1981.

Didi-Huberman, Georges. Sortir du noir. Paris: Les Editions de Minuit, 2015.

Dwork, Debórah and Robert Jan van Pelt. Auschwitz, 1270 to the Present. New York and London: W.W. Norton \& Company, 1996.

Frankl, Victor. Man's Search for Meaning: An Introduction to Logotherapy. New York: Simon \& Schuster, 1984.

Mark, Ber (Editor). The Scrolls of Auschwit. Tel Aviv: Am Oved Publishers, 1985.

Nyiszl, Miklós. Auschwitz: A Doctor's Eyewitness Account. Translated by Tibére Kremer and Richard Seaver. New York: Arcade Publishing, 1993.

Rousset, David. L'univers concentrationnaire. Paris: Editions de Pavois, 1946.

Stangneth, Bettina. Eichmann before Jerusalem: The Unexamined Life of a Mass Murderer. Toronto: Random House of Canada, 2014.

Van Pelt, Robert Jan. The Case for Auschwitz: Evidence from the Irving Trial. Bloomington and Indianapolis: Indiana UP, 2002.

Webber, Jonathan. The Future of Auschwitz: Some Personal Reflections. Oxford: Oxford Centre for Postgraduate Hebrew Studies, 1992.

Yahil, Leni. The Holocaust: The Fate of European Jewry, 1932-1945. New York: Oxford University Press, 1990. 